\title{
VALUASI BISNIS PERUSAHAAN PT JAMINAN PEMBIAYAAN ASKRINDO SYARIAH DALAM RANGKA IPO DI TAHUN 2022
}

\author{
Bunga Mareti Permatasari ${ }^{1}$, Zulkifli ${ }^{2}$, Syamsul Bahri ${ }^{3}$ \\ 1, 2,3 Magister Manajemen, Sekolah Pascasarjana, Universitas Pancasila \\ Email : bungamareti87@gmail.com
}

\begin{abstract}
ABSTRAK
Dalam rangka menyerap potensi bisnis penjaminan syariah di masa mendatang yang akan berkembang pesat, PT Jaminan Pembiayaan Askrindo Syariah dengan brandname "Askrindo Syariah" akan melaksanakan aksi korporasi salah satu nya initial public offering (IPO) di tahun 2022. Kinerja Askrindo Syariah menunjukan peningkatan dalam 5 tahun terakhir. Namun, profil bisnis Askrindo Syariah yang sebagian besar pada produk berisiko tinggi menunjukan tidak optimalnya kinerja perusahaan meskipun mengalami peningkatan. Maka Askrindo Syariah perlu menetapkan strategi dalam rangka persiapan IPO. Tujuan penelitian ini adalah untuk mengetahui valuasi bisnis strategi perusahaan PT Jaminan Pembiayaan Askrindo Syariah Terkait Rencana initial public offering (IPO) di Tahun 2022. Hasil penelitian menunjukan rentang nilai wajar harga saham terkait keputusan Askrindo Syariah melaksanakan IPO di tahun 2022, berdasarkan perhitungan free cash flow to equity nilai perusahaan di tahun 2022 adalah sebesar Rp 2.111.814,- per lembar saham, sedangkan berdasarkan valuasi relatif nilai book value adalah sebesar Rp 2.331.168,- per lembar saham. Hasil penelitian ini juga dapat ditentukan valuasi bisnis pada tahun 2025 nilai perusahaan berdasarkan perhitungan menggunakan metode free cash floe to equity adalah sebesar Rp2.929.706,- per lembar saham sedangkan berdasarkan metode book value adalah sebesar Rp3.383.228,--. per lembar saham untuk mempertahankan nilai perusahaan sebagaimana yang telah diproyeksikan, maka Askrindo Syariah perlu untuk menerapkan strategi perusahaan penetrasi pasar pada produk dengan kualitas underwritting yang baik.
\end{abstract}

Kata Kunci: Valuasi bisnis, Strategi Perusahaan, Initial public offering, Penjamin syariah

\begin{abstract}
In order to absorb the potential of the sharia guarantee business in the future which will grow rapidly, PT Jaminan Pembiayaan Askrindo Syariah with the brand name "Askrindo Syariah" will carry out corporate actions, one of which is an initial public offering (IPO) in 2022. Askrindo Syariah's performance shows an increase in 5 years. However, Askrindo Syariah's business profile, which is mostly high-risk products, shows that the company's performance is not optimal even though it has increased. Accordingly, Askrindo Syariah needs to set a strategy in preparation for the IPO. The purpose of this study was to determine the business valuation of the company's strategy for Askrindo Syariah related to the initial public offering (IPO) plan in 2022. The results of the study show that the fair value range of share prices related to Askrindo Syariah's decision to carry out an IPO in 2022, based on the calculation of free cash flow to equity, the value of the company in 2022 is IDR 2,111,814 per share, while based on the relative valuation the book value is amounting to $R p 2,331,168,-$ per share. The results of this study can also determine the business valuation in 2025, the value of the company based on calculations using the FCFE method is Rp.2,929,706, - while based on the book value method is Rp.3,383,228,-. To maintain the company's value as projected, Askrindo Syariah needs to implement a company strategy to reach good underwritting quality product.
\end{abstract}

Keyword: Business valuation, Company strategy, Initial public offering, Sharia Guarantee 


\section{PENDAHULUAN}

Sebagai salah satu penyokong roda perekonomian Indonesia, industri perusahaan penjaminan memberikan peran yang cukup penting. Walaupun di Indonesia pamor bisnis penjaminan kredit belum populer layaknya bisnis bank atau asuransi, perusahaan penjaminan bermanfaat sebagai pendukung akses untuk mendapatkan status layak kredit. Perusahaan Penjamin, dalam hal ini, memberikan jasa penjaminan bagi kredit dan pembiayaan, serta bertanggungjawab memberikan ganti rugi kepada penerima jaminan apabila terjadi kegagalan penerima kredit dalam memenuhi kewajibannya (Amri, 2021).

Perusahaan penjaminan yang tergabung dalam Asippindo salah satunya terdapat pada perusahaan penjaminan konvensional dan syariah. Berdasarkan Peraturan Otoritas Jasa Keuangan (POJK) Nomor 2/POJK.05/2017 tentang Perusahaan Penjaminan. Penjaminan adalah kegiatan pemberian jaminan oleh Penjamin atas pemenuhan kewajiban finansial Terjamin kepada Penerima Jaminan. Sedangkan Penjaminan Syariah adalah kegiatan pemberian jaminan oleh Penjamin atas pemenuhan kewajiban finansial Terjamin kepada Penerima Jaminan berdasarkan Prinsip Syariah (Ramadhi et al., 2021).

PT Jaminan Pembiayaan Askrindo Syariah (Askrindo Syariah) merupakan perusahaan yang pertama berdiri yakni tahun 2012 di industri penjaminan pembiayaan berbasis syariah. Hingga pada tahun 2014, Perum Jamkrindo mendirikan anak perusahaan yakni PT Penjaminan Jamkrindo Syariah, yang memiliki kesamaan bisnis dengan Askrindo Syariah. Oleh karena itu, dengan muncul nya kompetitor tersebut Askrindo Syariah harus menetapkan strategi bisnis demi menjaga eksistensi sebagai pioneer penjaminan syariah dan market leader (Amri \& Ramdani, 2020).

Seiring dengan bertumbuhnya kredit atau pembiayaan yang dikucurkan oleh perbankan syariah maupun institusi keuangan non bank syariah, maka semakin meningkat pula potensi bisnis bagi Askrindo Syariah. Selain itu dengan banyaknya kebutuhan akan penjaminan bank garansi serta surety bond tentunya semakin membuka pangsa pasar yang luas bagi Askrindo Syariah. Sebagaimana data pembiayaan perbankan syariah yang tertera pada Statistik Perbankan Syariah Otoritas Jasa Keuangan menunjukan pertumbuhan yang terus meningkat, sebagaimana yang tertera pada tabel dan grafik di bawah ini: 
Tabel 1. Pembiayaan Perbankan Syariah Tahun 2016-2020

Angka dalam milyar $R p$

\begin{tabular}{|c|c|c|c|c|c|}
\hline Uraian & 2016 & 2017 & 2018 & 2019 & 2020 \\
\hline $\begin{array}{l}\text { Pembiayaan Bank Umum Syariah \& Unit Usaha } \\
\text { Syariah }\end{array}$ & 248.007 & 285.695 & 320.193 & 355.182 & 388.862 \\
\hline Pembiayaan Bank Perkreditan Rakyat Syariah & 6.663 & 7.764 & 9.084 & 9.943 & 11.063 \\
\hline Total Pembiayaan Bank Syariah & 254.670 & 293.459 & 329.277 & 365.125 & 399.925 \\
\hline
\end{tabular}

Sumber: Statistik Perbankan Syariah Otoritas Jasa Keuangan

Dalam kurun waktu 5 tahun terakhir laju pertumbuhan industri perbankan syariah menunjukan peningkatan yang cukup signifikan. Hal tersebut merupakan hasil konversi Bank Pembangunan Daerah sebagai implementasi peraturan daerah syariah. Semakin berkembangnya halal lifestyle dan komitmen pemerintah dalam memajukan perekonomian syariah melalui Komite Nasional Keuangan Syariah (KNKS) juga turun meningkatkan pangsa pasar bagi perbankan syariah.

Industri Keuangan Non-Bank Syariah tampak nya menunjukan kinerja yang tidak sebaik perbankan syariah. Dalam kurun waktu 5 tahun terakhir, perusahaan pembiayaan syariah menunjukan tingkat non performing financing (NPF) sebesar 5,1\% pada kuartal II tahun 2020 yang merupakan tingkat tertinggi (Pratama, 2020). Adapun penurunan kinerja perusahaan pembiayaan syariah ini telah tampak pada tahun 2018. Berdasarkan statistik IKNB Syariah Otoritas Jasa Keuangan tahun 2018, menunjukan penurunan outstanding pembiayaan dari perusahaan pembiayaan syariah. Hal tersebut merupakan implikasi dari peningkatan NPF perusahaan pembiayaan syariah yang tinggi. Adapun kondisi pembiayaan dari IKNB Syariah dapat tertera pada tabel di bawah ini:

Tabel 2. Pembiayaan Industri Keuangan Non-Bank Syariah Tahun 2016-2020 Angka dalam milyar $R p$

\begin{tabular}{l|r|r|r|r|r|r|}
\multicolumn{1}{c|}{ IKNB } & \multicolumn{1}{c|}{$\mathbf{2 0 1 5}$} & \multicolumn{1}{c|}{$\mathbf{2 0 1 6}$} & $\mathbf{2 0 1 7}$ & $\mathbf{2 0 1 8}$ & \multicolumn{1}{c|}{$\mathbf{2 0 1 9}$} & \multicolumn{2}{c}{2020} \\
\hline Modal Ventura Syariah & 401 & 753 & 870 & 884 & 2.321 & 2.113 \\
Pembiayaan Syariah & 18.399 & 31.451 & 28.645 & 20.014 & 15.987 & 11.610 \\
Lembaga Mikro Syariah & 3,4 & 8,8 & 12,0 & 15,4 & 20,2 & 26,1 \\
Pegadaian Syariah & 3.749 & 4.572 & 5.222 & 7.094 & 10.556 & 10.692 \\
TOTAL & $\mathbf{2 2 . 5 5 3}$ & $\mathbf{3 6 . 7 8 4}$ & $\mathbf{3 4 . 7 5 0}$ & $\mathbf{2 8 . 0 0 7}$ & $\mathbf{2 8 . 8 8 4}$ & $\mathbf{2 4 . 4 4 1}$ \\
\hline
\end{tabular}

Kinerja Askrindo Syariah sendiri mengalami peningkatan yang terus berkelanjutan dari tahun ke tahun. Hal tersebut terbukti dengan prestasi yang diukir oleh Askrindo Syariah pada tahun 2020 yang berhasil menerima penghargaan "Emerging Stated Owned 
Enterprises" di acara 9th Anugerah BUMN 2020 yang diselenggarakan oleh BUMN Track (Suryanto, 2020). Didukung oleh implementasi strategi secara efektif dan penuh kehatihatian, Askrindo Syariah berhasil membukukan kinerja yang baik pada tahun 2019. Secara keseluruhan, Askrindo Syariah mencatat total penjaminan sebesar Rp10,09 triliun pada tahun 2019, menurun 3,25\% dibandingkan Rp10,43 triliun pada tahun 2018. Dari segmen produktif, produk Penjaminan Mikro masih menjadi kontributor terbesar mencapai $66,56 \%$ dari total penjaminan di segmen produktif. Di sisi lain, untuk segmen konsumtif, Penjaminan Implan mencatat kontribusi sebesar 49,88\% dengan nilai klaim sebesar 26,07\%. Melalui Divisi Non Cash Financing, Askrindo Syariah berhasil membukukan Pendapatan Ujroh sebesar Rp12,56 miliar dari target sebesar Rp20 miliar. Capaian ini dinilai cukup baik mengingat peluang pertumbuhan Divisi Non Cash Financing di tahun mendatang serta lost ratio yang relatif kecil dibandingkan target.

Adapun highlight kinerja Askrindo Syariah dalam kurun waktu 5 tahun terakhir dapat diuraikan pada tabel di bawah ini:

Tabel 3. Highlight Kinerja Keuangan Audited Askrindo Syariah Tahun 2015-2019 Angka dalam juta $R p$

\begin{tabular}{lrrrrr} 
Tren Kinerja Keuangan & $\mathbf{2 0 1 5}$ & \multicolumn{1}{c}{$\mathbf{2 0 1 6}$} & $\mathbf{2 0 1 7}$ & \multicolumn{1}{c}{$\mathbf{2 0 1 8}$} & \multicolumn{1}{c}{$\mathbf{2 0 1 9}$} \\
\hline IJK Bruto & 111.149 & 156.216 & 176.300 & 223.485 & 317.280 \\
Hasil Underwritting Bersih & 53.398 & 60.766 & 41.690 & 80.932 & 122.951 \\
Hasil Investasi & 10.728 & 15.613 & 16.965 & 12.655 & 20.028 \\
Laba Bersih & 24.036 & 20.484 & 6.226 & 14.085 & 36.562 \\
& & & & & \\
Aset & 326.737 & 357.209 & 391.355 & 401.228 & 622.709 \\
Aset Investasi & 305.755 & 327.737 & 318.885 & 349.848 & 527.262 \\
Aset Non Investasi & 20.982 & 29.472 & 72.470 & 51.380 & 95.447 \\
& & & & & \\
Aset & 326.737 & 357.209 & 391.355 & 401.228 & 622.709 \\
Ekuitas & 284.743 & 304.176 & 310.636 & 325.531 & 510.375
\end{tabular}

Catatan : Laporan Keuangan Audited Tahun 2020 akan dipublikasi pada akhir Juni 2021

Pada tahun 2020, Askrindo Syariah menjadi member dari Indonesia Financial Group (IFG). Dengan konsolidasi aset sebesar Rp72,5 triliun per Maret 2020, IFG memiliki 9 anggota holding di antaranya PT Asuransi Kredit Indonesia (Askrindo), PT Jaminan Kredit Indonesia (Jamkrindo), PT Jasa Raharja, dan PT Asuransi Jasa Indonesia (Jasindo), PT Bahana Sekuritas, PT Bahana TCW Investment Management, PT Bahana Artha Ventura, PT Grahaniaga Tata Utama dan PT Bahana Kapital Investa. 
Dalam rangka memenuhi tuntutan atas kebutuhan pengembangan bisnis dan kapasitas perusahaan, selain dengan rencana di awal tahun 2021 yaitu pelaksanaan aksi korporasi penambahan modal disetor sebesar Rp250Milyar, Askrindo Syariah juga berencana melaksanakan penawaran saham perdana atau Initial Public Offering (IPO) di tahun 2022. Menurut Hartono dan Ali (2002), IPO merupakan penawaran saham di pasar perdana yang dilakukan perusahaan yang hendak go-public. Saham adalah satuan nilai atau pembukuan dalam berbagai instrumen finansial yang mengacu pada bagian kepemilikan sebuah perusahaan. Pasar perdana merupakan pasar dimana terjadi pembelian saham dari perusahaan (emiten) oleh investor untuk pertama kalinya. UU Republik Indonesia tahun No. 8 tahun 1995 tentang pasar modal mendefinisikan penawaran umum sebagai kegiatan penawaran yang dilakukan oleh emiten untuk menjual efek kepada masyarakat berdasarkan tata cara yang telah diatur dalam undangundang tersebut dan peraturan pelaksanaannya (Hartono dan Ali, 2002).

Terkait dengan hal tersebut di atas, maka Askrindo Syariah sangatlah perlu untuk merancang dan melaksanakan strategi perusahaan yang tepat untuk meningkatkan kinerja perusahaan agar lebih baik daripada sebelumnya. Pada Rencana Kerja dan Anggaran Perusahaan (RKAP) pada tahun 2020, strategi bisnis yang dilaksanakan oleh Askrindo Syariah lebih menitikberatkan pada kualitas portofolio bisnis. Sebagaimana tema pokok RKAP tahun 2020 yakni “Pertumbuhan Bisnis Penjaminan Syariah yang Potensial dan Berkualitas melalui Pelaksanaan Strategi yang Komprehensif serta menjaga Prinsip Prudent Underwritting". Lebih lanjut pada tahun 2021 Askrindo Syariah berupaya untuk meningkatkan inovasi ayanan dan produk nya, sebagaimana tema RKAP tahun 2021 yang diusung yakni “Peningkatan Kinerja melalui Inovasi Bisnis dan Layanan Digital”.

Akan tetapi, realisasi RKAP tahun 2020 pada semester 2, menunjukan sebagian besar, lebih dari 70\%, portofolio produk Askrindo Syariah berada pada produk-produk dengan kualitas underwriiting yang rendah. Produk tersebut berkarakteristik risiko klaim tinggi, rendahnya pendapatan premi yang diakui sebagai pendapatan karena memiliki masa tenor kredit yang lebih dari 1 tahun dan pembayaran jatuh tempo premi pada tahun berikutnya. Hal tersebut menyebabkan, walaupun kinerja perusahaan meningkat, namun tidak memberikan peningkatan kinerja yang optimal. 
Seiring dengan keberlangsungan bisnis yang telah dijalankan selama 8 tahun sejak pertama kali berdiri, peneliti ingin menerapkan analisis penilaian harga wajar saham atas nilai perusahaan Askrindo Syariah saat ini. Saat perusahaan berdiri pada tahun 2012, nilai buku harga saham adalah sebesar Rp1juta per lembar saham. Tahun 2019 tepat nya saat persiapan merger dengan Indonesia Financial Group (IFG) , ditunjuk suatu Kantor Jasa Penilaian Publik (KJPP) untuk melaksanakan valuasi bisnis terhadap harga saham Askrindo Syariah. Hasil penilaian nilai buku harga saham yang dilaksanakan oleh KJPP, harga saham Askrindo Syariah tetap berada pada Rp1juta per lembar saham. Oleh karena itu, dengan kondisi perusahaan yang terus mengalami perkembangan, tentu perlu dilakukan penilaian harga saham di tahun 2021 ini, yang dapat dijadikan landasan untuk menentukan harga penawaran saham perdana Askrindo Syariah.

Adapun penentuan nilai wajar harga saham pada penawaran perdana ini sangatlah penting, untuk menjaring investor. Apabila harga terlalu tinggi tentu akan menurunkan minat investor untuk berinvestasi pada saham Askrindo Syariah. Apabila harga yang ditawarkan terlalu rendah, maka dana penambahan modal yang akan didapatkan oleh Askrindo Syariah tidak optimal. Di sisi lain, dalam kurun waktu 5 tahun mendatang Askrindo Syariah perlu untuk tetap mempertahankan bahkan meningkatkan nilai perusahaannya. Untuk itu perlu diterapkan strategi yang tepat untuk mempertahankan nilai perusahaan tersebut. Oleh karena itulah, peneliti tertarik melakukan penelitian dengan judul "Valuasi Bisnis Perusahaan PT Jaminan Pembiayaan Askrindo Syariah Dalam Rangka IPO di Tahun 2022".

\section{METODE PENELITIAN}

Menurut Sugiyono (2013), penelitian deskriptif adalah penelitian dengan metode untuk menggambarkan suatu hasil penelitian. Namun, hasil gambaran tersebut tidak digunakan untuk membuat kesimpulan yang lebih umum. Lebih lanjut, menurut Mardalis (2008) penelitian deskriptif bertujuan untuk mendeskripsikan apa-apa yang saat ini berlaku, di dalamnya terdapat upaya mendeskripsikan, mencatat, analisis, dan menginterpretasikan kondisi-kondisi yang sekarang ini terjadi atau ada. Jenis penelitian ini yang digunakan adalah penelitian deskriptif yaitu dengan mengumpulkan data-data 
yang diperlukan, kemudian dianalisa menggunakan analisis meliputi analisa laporan keuangan, analisa manajemen strategi perusahaan, analisa valuasi nilai wajar harga saham melalui metode price book value (PBV) dan market value serta proyeksi kinerja perusahaan 5 tahun yang akan datang. Hasil deskriptif penelitian ini merupakan nilai wajar harga saham serta posisi perusahaan saat ini dan di 5 tahun mendatang. Oleh karena itu hasil deskriptif yang diperoleh pada penelitian ini hanya menggambarkan kondisi PT Jaminan Pembiayaan Askrindo Syariah.

Objek penelitian dalam penelitian ini adalah data-data kinerja keuangan tahun 2016 sampai dengan 2020 serta anggaran dan rencana kerja jangka pendek maupun jangka panjang PT Jaminan Pembiayaan Askrindo Syariah. Selain itu, penelitian ini menggunakan metode studi literatur untuk menganalisa kinerja keuangan. Metode studi literatur dilaksanakan dengan menggunakan data sekunder. Data tersebut disebut sebagai data sekunder karena diperoleh secara tidak langsung, yakni diperoleh dari berbagai media yaitu :

1. Annual Report (Laporan Kinerja Tahunan) PT Jaminan Pembiayaan Askrindo Syariah dalam kurun waktu 2016 sampai dengan 2020.

2. Rencana Kerja dan Anggaran Perusahaan (RKAP) PT Jaminan Pembiayaan Askrindo Syariah Tahun 2020 dan 2021.

3. Rencana Jangka Panjang Perusahaan (RJPP) PT Jaminan Pembiayaan Askrindo Syariah Tahun 2020 dan 2024.

4. Statistik Perbankan Syariah Otoritas Jasa Keuangan (OJK) Tahun 2016 - 2020, yang didapatkan melalui website OJK.

5. Statistik Industri Keuangan Non Bank (IKNB) Syariah Otoritas Jasa Keuangan (OJK) Tahun 2016 - 2020, yang didapatkan melalui website OJK.

6. Masterplan Ekonomi Syariah 2019-2024, yang didapatkan dari Kementerian Perencanaan Pembangunan Nasional Republik Indonesia.

7. Master Plan Sektor Jasa Keuangan Indonesia 2021-2025 dan Roadmap Pengembangan Perbankan Syariah Indonesia 2020-2025, yang di dapatkan dari website Otoritas Jasa Keuangan. 
8. Rancangan Anggaran Pendapatan Negara (APBN) Tahun 2021, Realisasi APBN 20162020 dan Realisasi APBN Triwulan I Tahun 2021, yang didapatkan dari website Kementrian Keuangan Republik Indonesia.

9. Data-data sekunder pendukung lainnya yang dibutuhkan selama penelitian.

Menganalisis strategi perusahaan menggunakan teknik pengambilan data adalah focus group discussion (FGD). Analisis data dalam penelitian ini dengan cara mengklasifikasikan dan menghitung rasio-rasio keuangan perusahaan dalam kurun waktu 5 tahun terakhir yang akan dilaksanakan berdasarkan teori rasio-rasio dalam laporan keuangan, antara lain: Rasio aktivitas, Rasio likuiditas, Rasio Solvabilitas, Rasio Profitabilitas. Selain itu sebagai bagian dalam analisa laporan keuangan ini, juga dilaksanakan penilaian Tingkat Kesehatan Keuangan Perusahaan Penjaminan sesuai dengan Peraturan Otoritas Jasa Keuangan. Proses pengolahan data menggunakan program microsoft excel. Tahapan penelitian dimulai dari Analisa laporan keuangan, valuasi bisnis dan penentuan nilai wajar perusahaan saat ini, proyeksi laporan keuangan 5 tahun mendatang, analisis valuasi bisnis, penetapan nilai perusahaan 5 tahun mendatang, penentuan harga saham perdana IPO tahun 2022, dan analisis manajemen strategi.

\section{HASIL DAN PEMBAHASAN}

a. Valuasi Bisnis Atas Realisasi Tahun 2020 dan Proyeksi Tahun 2021- 2025

\section{Valuasi Bisnis Melalui Metode Discounted Cash Flow}

Berdasarkan laporan keuangan yang telah diproyeksikan, akan dilakukan valuasi bisnis melalui metode Discounted Cash Flow DCF yakni Free Cash Flow to Equity (FCFE). Pelaksanaan IPO direncanakan pada tahun 2022 atau paling cepat akhir 2021. Oleh karena itu laporan keuangan proyeksi tahun 2021 - 2025 akan menjadi dasar dalam valuasi ini. Berikut adalah langkah-langkah perhitungan perhitungan FCFE.

\section{a) Estimasi tingkat pertumbuhan}

$$
\mathrm{g}=\mathrm{ROE} \times \mathrm{r} \text { retention rate }
$$

Tabel 4. Tingkat Pertumbuhan Tahun 2020 - 2025

angka dalam juta $R p$ 


\begin{tabular}{l|c|c|r|r|r|r|}
\multicolumn{1}{c|}{ Uraian } & $\begin{array}{c}\text { Realisasi } \\
\mathbf{2 0 2 0}\end{array}$ & $\mathbf{2 0 2 1}$ & $\mathbf{2 0 2 2}$ & $\mathbf{2 0 2 3}$ & $\mathbf{2 0 2 4}$ & $\mathbf{2 0 2 5}$ \\
\hline Ekuitas & 543.307 & 849.890 & 932.467 & 1.043 .099 & 1.183 .816 & 1.353 .291 \\
EAT & 32.748 & 56.582 & 82.578 & 110.632 & 140.717 & 169.475 \\
ROE & $6,0 \%$ & $6,7 \%$ & $8,9 \%$ & $10,6 \%$ & $11,9 \%$ & $12,5 \%$ \\
\hline Laba ditahan & 32.748 & 56.582 & 82.578 & 110.632 & 140.717 & 169.475 \\
Retention rate & $100,0 \%$ & $100,0 \%$ & $100,0 \%$ & $100,0 \%$ & $100,0 \%$ & $100,0 \%$ \\
g & $6,0 \%$ & $6,7 \%$ & $8,9 \%$ & $10,6 \%$ & $11,9 \%$ & $12,5 \%$
\end{tabular}

\section{b) Menentukan Cost of Debt}

Cost of Debt adalah biaya yang harus dibayar oleh suatu lembaga keuangan atau bank atas penggunaan uang yang sumbernya dari pihak lain. Dalam laporan keuangan Askrindo Syariah, nilai Cost of Debt $=0$. Karena Askrindo Syariah tidak memiliki hutang pinjaman yang dibebankan bunga.

\section{c) Menentukan Cost of Equity}

Cost of equity merupakan tingkat pengembalian yang diharapkan oleh para investor terhadap dana yang mereka investasikan di perusahaan tersebut. Salah satu pendekatan yang banyak dipergunakan untuk melakukan estimasi cost of equity adalah dengan menggunakan CAPM (Capital Asset Pricing Model) (Damodaran, 2012). Adapun persamaan nya adalah sebagai berikut:

$\mathrm{Ke}=\mathrm{Rf}+\boldsymbol{\beta}(\mathrm{Rm}-\mathrm{Rf})$

$\mathrm{Rf}=$ nilai risk-free rate, $\beta=$ systematic risk dari ekuitas perusahaan di mana nilainya didapat dari hasil regresi return dari saham perusahaan tersebut terhadap market return $(\mathrm{Rm}-\mathrm{Rf})=$ merupakan nilai expected equity risk premium Berdasarkan metode CAPM, tingkat pengembalian yang disyaratkan investor diperoleh dari tingkat suku bunga bebas risiko ditambah dengan perkalian antara beta perusahaan dengan premi risiko. Adapun hasil perhitungan cost of equity :

\section{Tabel 5. Hasil Perhitungan Cost of Equity}

\begin{tabular}{l|r|l}
\multicolumn{1}{c|}{ Uraian } & \multicolumn{1}{c}{ Nilai } & \multicolumn{1}{c}{ Keterangan } \\
$\mathrm{Rf}$ & 7,1 Obligasi \\
$\mathrm{Rm}-\mathrm{Rf}$ & 5,87 Damodaran (equity risk premium indonesia) \\
beta & 0,68 Damodaran (beta insurance industry) \\
Cost of Equity (\%) & $11,09 \mathrm{Ke}=\mathrm{Rf}+\beta(\mathrm{Rm}-\mathrm{Rf})$
\end{tabular}

d) Menentukan Fre Cash Flow To Equity (FCFE) 
FCFE diambil dari laporan kuangan dan dihitung dengan mengurangi laba bersih dengan kebutuhan investasi dan menjumlahkan semua transaksi non kas seperti deperesiasi. Kemudian dikurangi modal kerja non kas dan ditambahkan dengan net kas masuk dari penerbitan utang.

Berikut adalah rumus perhitungan nya:

NCFE $=$ NIAT + NCC - CAPEX - CNWC + NCLTD

Keterangan:

NIAT $=$ Net Income after tax

NCC $=$ Non Cash Charge

CAPEX $=$ Capital Expenditure

CNWC $=$ Change in Net Working Capital

NCLTD $=$ Net Change in Long Term Debt

Berdasarkan rumus perhitungan di atas, maka didapat hasil perhitungan nya sebagai berikut:

\section{Tabel 6. Hasil Perhitungan FCFE}

angka dalam juta $R p$

\begin{tabular}{|c|c|c|c|c|c|c|}
\hline Uraian & $\begin{array}{c}\text { Realisasi } \\
2020\end{array}$ & 2021 & 2022 & 2023 & 2024 & 2025 \\
\hline Net Income After Tax (NIAT) & 32.748 & 56.582 & 82.578 & 110.632 & 140.717 & 169.475 \\
\hline Depresiasi Amortisasi (NCC) & 6.525 & 4.896 & 4.080 & 5.330 & 6.388 & 7.204 \\
\hline Perubahan working capital (CNWC) & $(378.840)$ & (423.197) & $(297.580)$ & $(318.623)$ & $(347.951)$ & (398.858) \\
\hline perubahan cap expenditure (CAPEX) & 0 & 2.300 & $(1.600)$ & (700) & - & $(5.700)$ \\
\hline Perubahan Hutang jangka panjang (NCLTD) & - & 507 & 1.118 & 878 & 1.010 & 1.935 \\
\hline FCFE $=$ NIAT + NCC - CAPEX - CNWC +CNLTD & 418.112 & 482.883 & 386.955 & 436.162 & 496.066 & 583.171 \\
\hline
\end{tabular}

\section{e) MenetapkanTerminal Value}

Dengan asumsi bahwa perusahaan akan terus beroperasi (going concern), maka proyeksi terhadap laporan keuangan dibatasi oleh 2 kondisi. Kondisi pertama merupakan kondisi di mana perusahaan akan tumbuh tinggi, setelah itu memasuki kondisi kedua dengan pertumbuhan stabil. Pertumbuhan yang stabil ini menjadi acuan penetapan terminal value dari nilai ekuitas. Adapun rumus perhitungan nya adalah sebagai berikut:

Terminal Value $=($ FCFE $n+1):($ Kest - gn $)$

Keterangan: 
FCFEn+1 = arus kas bersih pada tahun $\mathrm{n}$

$\mathrm{Ke}, \mathrm{st}=$ cost of equity periode stable growth

gn = tingkat pertumbuhan stabil

Hasil perhitungan nya dapat dilihat pada tabel berikut:

Tabel 7. Terminal Value Tahun 2020 - 2025

angka dalam juta $R p$

\begin{tabular}{|c|c|c|c|c|c|c|}
\hline Uraian & 2020 & 2021 & 2022 & 2023 & 2024 & 2025 \\
\hline Constant Growth \% & 6 & 7 & 9 & 11 & 12 & 13 \\
\hline FCFE tahun $n+1$ & 760.356 & 1.014 .974 & 1.244 .230 & 1.498 .862 & 1.872 .190 & 2.106 .214 \\
\hline Cost of Equity (\%) & 11 & 11 & 11 & 11 & 11 & 11 \\
\hline Terminal Value & 149.335 & 248.063 & 594.870 & 3.048 .947 & $(2.315 .920)$ & (1.495.466) \\
\hline
\end{tabular}

\section{f) Estimasi Nilai Wajar Ekuitas}

Dalam konsep pendekatan pendapatan/discounted cash flow dengan free cash flow to equity model, estimasi nilai wajar ekuitas merupakan penjumlahan dari nilai kini equity dan terminal value. Berikut perhitungan nilai ekuitas per lembar saham Askrindo Syariah:

Tabel 8. Hasil Perhitungan Nilai Wajar Ekuitas Tahun 2020

angka dalam juta $R p$

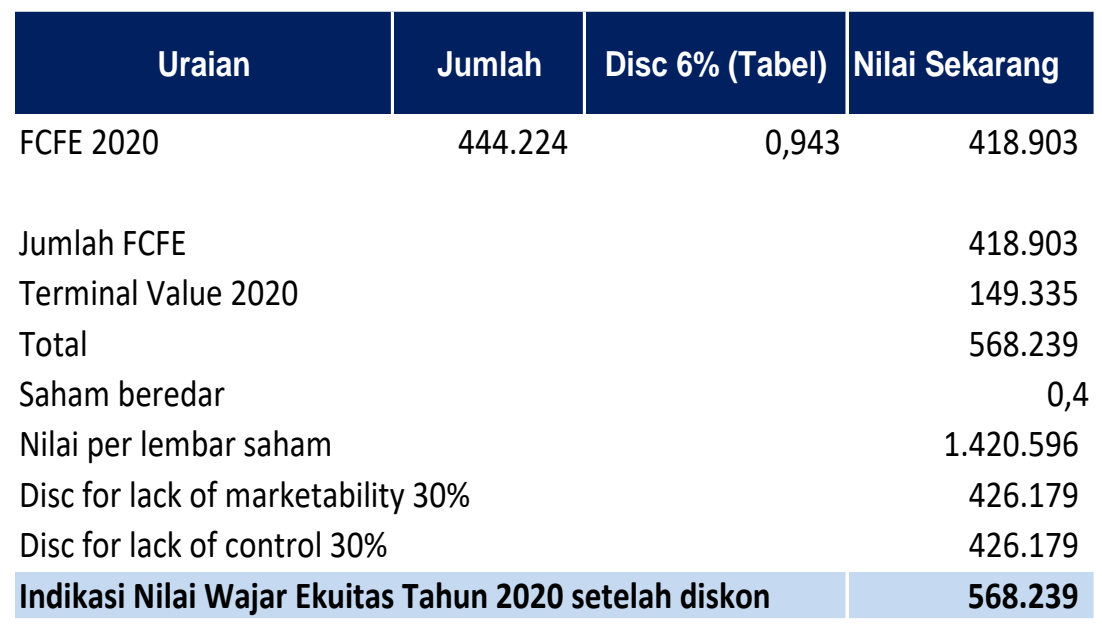

Tabel 9. Hasil Perhitungan Nilai Wajar Ekuitas Tahun 2021

angka dalam juta $R p$ 


\begin{tabular}{|c|c|c|c|}
\hline Uraian & Jumlah & Disc 7\% (Tabel) & Nilai Sekarang \\
\hline FCFE 2020 & 444.224 & 0,93458 & 415.163 \\
\hline FCFE 2021 & 760.356 & 0,87344 & 664.125 \\
\hline Jumlah FCFE & & & 1.079 .288 \\
\hline Terminal Value 2021 & & & 248.063 \\
\hline Total & & & 1.327 .351 \\
\hline Saham beredar & & & 0,4 \\
\hline Nilai per lembar saham & & & 3.318 .378 \\
\hline Disc for lack of marketability $30 \%$ & & & 995.513 \\
\hline Disc for lack of control $30 \%$ & & & 995.513 \\
\hline Indikasi Nilai Wajar Ekuitas Tahun 2021 setelah diskon & & & 1.327 .351 \\
\hline
\end{tabular}

\section{Tabel 10. Hasil Perhitungan Nilai Wajar Ekuitas Tahun 2022}

angka dalam juta $R p$

\begin{tabular}{|c|c|c|c|}
\hline Uraian & Jumlah & Disc 9\% (Tabel) & Nilai Sekarang \\
\hline FCFE 2020 & 444.224 & 0,8415 & 373.814 \\
\hline FCFE 2021 & 760.356 & 0,7081 & 538.408 \\
\hline FCFE 2022 & 1.014 .974 & 0,5958 & 604.722 \\
\hline Jumlah FCFE & & & 1.516 .944 \\
\hline Terminal Value 2021 & & & 594.870 \\
\hline Total & & & 2.111 .814 \\
\hline Saham beredar & & & 0,4 \\
\hline Nilai per lembar saham & & & 5.279 .536 \\
\hline Disc for lack of marketability $30 \%$ & & & 1.583 .861 \\
\hline Disc for lack of control $30 \%$ & & & 1.583 .861 \\
\hline Indikasi Nilai Wajar Ekuitas Tahun 2022 setelah diskon & & & 2.111 .814 \\
\hline
\end{tabular}

\section{Tabel 11. Hasil Perhitungan Nilai Wajar Ekuitas Tahun 2023}

angka dalam juta $R p$

\begin{tabular}{l|r|r|r}
\multicolumn{1}{c|}{ Uraian } & \multicolumn{1}{c|}{ Jumlah } & \multicolumn{1}{c|}{$\begin{array}{c}\text { Disc 11\% } \\
\text { (Tabel) }\end{array}$} & Nilai Sekarang \\
\hline FCFE 2020 & 444.224 & 0,9009 & 400.201 \\
FCFE 2021 & 760.356 & 0,8116 & 617.120 \\
FCFE 2022 & 1.014 .974 & 0,7312 & 742.139 \\
FCFE 2023 & 1.244 .230 & 0,6587 & 819.612 \\
& & & 2.579 .073 \\
Jumlah FCFE & & & 3.048 .947 \\
Terminal Value 2021 & & & 5.628 .020 \\
Total & & & 0,4 \\
Saham beredar & & & 14.070 .050 \\
Nilai per lembar saham & & 4.221 .015 \\
Disc for lack of marketability 30\% & & 4.221 .015 \\
Disc for lack of control 30\% & & $\mathbf{5 . 6 2 8 . 0 2 0}$
\end{tabular}

\section{Tabel 12. Hasil Perhitungan Nilai Wajar Ekuitas Tahun 2024}

angka dalam juta $R p$ 


\begin{tabular}{l|r|r|r}
\multicolumn{1}{c|}{ Uraian } & \multicolumn{1}{c|}{ Jumlah } & \multicolumn{1}{c|}{$\begin{array}{c}\text { Disc 12\% } \\
\text { (Tabel) }\end{array}$} & Nilai Sekarang \\
\hline FCFE 2020 & 444.224 & 0,8929 & 396.630 \\
FCFE 2021 & 760.356 & 0,7972 & 606.148 \\
FCFE 2022 & 1.014 .974 & 0,7118 & 722.438 \\
FCFE 2023 & 1.244 .230 & 0,6355 & 790.733 \\
FCFE 2024 & 1.872 .190 & 0,5674 & 1.062 .337 \\
& & & \\
Jumlah FCFE & & & 3.578 .287 \\
Terminal Value 2024 & & & $(2.315 .920)$ \\
Total & & & 1.262 .366 \\
Saham beredar & & & 0,4 \\
Nilai per lembar saham & & & 3.155 .916 \\
Disc for lack of marketability 30\% & & 946.775 \\
Disc for lack of control 30\% & & 946.775 \\
Indikasi Nilai Wajar Ekuitas Tahun 2024 setelah diskon & & & $\mathbf{1 . 2 6 2 . 3 6 6}$ \\
\hline
\end{tabular}

\section{Tabel 13. Hasil Perhitungan Nilai Wajar Ekuitas Tahun 2025}

angka dalam juta $R p$

\begin{tabular}{l|r|r|r|}
\hline \multicolumn{1}{c|}{ Uraian } & Jumlah & \multicolumn{1}{c|}{$\begin{array}{c}\text { Disc 12\% } \\
\text { (Tabel) }\end{array}$} & Nilai Sekarang \\
\hline FCFE 2020 & 444.224 & 0,8929 & 396.630 \\
FCFE 2021 & 760.356 & 0,7972 & 606.148 \\
FCFE 2022 & 1.014 .974 & 0,7118 & 722.438 \\
FCFE 2023 & 1.244 .230 & 0,6355 & 790.733 \\
FCFE 2024 & 1.872 .190 & 0,5674 & 1.062 .337 \\
FCFE 2025 & 1.872 .190 & 0,4524 & 846.885 \\
& & & \\
Jumlah FCFE & & & 4.425 .172 \\
Terminal Value 2025 & & & $(1.495 .466)$ \\
Total & & & 2.929 .706 \\
Saham beredar & & & 0,4 \\
Nilai per lembar saham & & & 7.324 .265 \\
Disc for lack of marketability 30\% & & & 2.197 .280 \\
Disc for lack of control 30\% & & & 2.197 .280 \\
Indikasi Nilai Wajar Ekuitas Tahun 2025 setelah diskon & & & $\mathbf{2 . 9 2 9 . 7 0 6}$ \\
\hline
\end{tabular}

\section{Valuasi Bisnis Melalui Metode Relative Valuation (Book Value)}

Untuk mengetahui seberapa besar harga saham lebih mahal daripada nilai bukunya dapat menggunakan analisa Book Value (BV). Book Value disingkat dengan BV, adalah rasio harga saham terhadap nilai buku perusahaan. BV digunakan untuk melihat seberapa besar kelipatan dari nilai pasar saham perusahaan dengan nilai bukunya. Berikut adalah tabel 4.10 yang menggambarkan perhitungan rasio Book Value pada saat penilaian sebelum IPO yakni tahun 2020 dan 2021, dengan cara menentukan terlebih dahulu Nilai Buku atas Ekuitas dengan memperhitungkan jumlah ekuitas berbanding jumlah saham yang beredar didapatkan perhitungan sebagai berikut: 
Nilai buku per lembar saham $=\underline{\text { Jumlah modal perusahaan }}$

Saham yang beredar

Tabel. 14. Perhitungan Book Value Tahun 2020 - 2025

\begin{tabular}{|l|c|c|r|r|r|r|}
\multicolumn{1}{|c|}{ Uraian } & $\begin{array}{c}\text { Realisasi } \\
\mathbf{2 0 2 0}\end{array}$ & $\mathbf{2 0 2 1}$ & $\mathbf{2 0 2 2}$ & $\mathbf{2 0 2 3}$ & $\mathbf{2 0 2 4}$ & $\mathbf{2 0 2 5}$ \\
\hline $\begin{array}{l}\text { Ekuitas (dalam juta Rp) } \\
\text { Jumlah Saham yang beredar }\end{array}$ & 543.307 & 849.890 & 932.467 & 1.043 .099 & 1.183 .816 & 1.353 .291 \\
$\begin{array}{l}\text { (dalam juta lembar) } \\
\text { Book Value }\end{array}$ & 0,4 & 0,4 & 0,4 & 0,4 & 0,4 & 0,4 \\
\hline
\end{tabular}

Berdasarkan perhitungan tabel di atas, nilai buku Askrindo Syariah saat ini pertahun buku 2020 adalah Rp1.358.269,-- Dan hasil perhitungan tersebut dapat digunakan untuk menentukan harga penawaran perdana saham Askrindo Syariah apa bila IPO akan dilaksanakan pada akhir tahun 2021 maka saran harga perdana yang ditawarkan adalah Rp 2.124.724,- dan di tahun 2022 harga nya adalah Rp. 2.331.168,. harga saham tersebut 2 kali lipat lebih mahal dari modal bersihnya. Apabila harga yang ditawarkan lebih rendah dari pada BV, maka saham Askrindo Syariah dapat dinilai undervalued. Meskipun saham jenis ini sering dijadikan indikator untuk investir yang mencari saham yang murah atau undervalued. Investor akan memilih untuk mencari saham dengan price book value yang lebih rendah daripada rata-rata price book value dalam industri sejenis.

Lebih lanjut apabila harga yang ditawarkan pada tahun 2021 lebih tinggi dari Rp 2.124.724,- dan di tahun 2022 lebih tinggi dari Rp.2.331.168,-. Maka saham Askrindo Syariah akan dinilai overvalue. Para investor akan tidak berminat dengan saham jenis ini.

3. Valuasi Bisnis Melalui Metode Relative Valuation (Price Earning Ratio \& Earning Per Share)

Pendekatan yang paling popular untuk mengestimasi harga wajar saham atau nilai intrinsik saham adalah dengan menggunakan pendekatan Price Earning Ratio (PER). Dalam Tandelilin (2010:320) dalam pendekatan PER atau disebut juga pendekatan multiplier, investor akan menghitung berapa kali berapa kali (multiplier) nilai earning yang tercermin dalam harga suatu saham. Rumus untuk menghitung PER adalah sebagai berikut:

\section{PER $=\quad$ Harga saham}




\section{Earning per lembar saham}

Sebelum menentukan nilai PER akan ditentukan dulu nilai earning per share (EPS). Berdasarkan proyeksi laporan keuangan yang telah dibuat, maka hasil perhitungan nilai EPS tahun 2020 sampai dengan tahun 2025 adalah sebagai berikut:

Tabel. 15. Perhitungan Earning Per Share Tahun 2020 - 2025

\begin{tabular}{|c|c|c|c|c|c|c|}
\hline Uraian & $\begin{array}{c}\text { Realisasi } \\
2020\end{array}$ & 2021 & 2022 & 2023 & 2024 & 2025 \\
\hline Laba setelah pajak (dalam juta Rp) & 32.748 & 56.582 & 82.578 & 110.632 & 140.717 & 169.475 \\
\hline \multicolumn{7}{|l|}{ Jumlah Saham yang beredar (dalam juta } \\
\hline lembar) & 0,4 & 0,4 & 0,4 & 0,4 & 0,4 & 0,4 \\
\hline Earning Per Share (dalam rupiah penuh) & 81.869 & 141.456 & 206.444 & 276.579 & 351.793 & 423.687 \\
\hline Growth Earning Per Share (dalam \%) & & $42,1 \%$ & $31,5 \%$ & $25,4 \%$ & $21,4 \%$ & $17,0 \%$ \\
\hline Rata-rata Growth (dalam \%) & & & & $27,5 \%$ & & \\
\hline
\end{tabular}

Semakin meningkat nilai EPS dari tahun ke tahun, maka perusahaan tersebut semakin baik karena laba perusahaan meningkat, serta perusahaan dapat dikatakan bertumbuh. Berdasarkan proyeksi 5 tahun ke depan, Askrindo Syariah menunjukan pertumbuhan earning per share yang selalu meningkat dari tahun 2020 hingga 2025. Lebih lanjut, bagi investor, menginvestasikan dana pada saham Askrindo Syariah akan profitable karena EPS akan meningkat sebesar $27,5 \%$ setiap tahun nya.

Dengan menghitung Earning per Share, maka kita dapat menentukan nilai Price to Earning Ratio, dengan harga penawaran saham diasumsikan sesuai harga book value. Adapun hasil perhitungan nya adalah sebagai berikut:

Tabel. 16. Perhitungan Price to Earning Ratio Tahun 2020 - 2025

\begin{tabular}{|c|c|c|c|c|c|c|}
\hline Uraian & $\begin{array}{c}\text { Realisasi } \\
2020\end{array}$ & 2021 & 2022 & 2023 & 2024 & 2025 \\
\hline Harga Saham (dalam rupiah penuh) & 1.358 .269 & 2.124 .724 & 2.331 .168 & 2.607 .748 & 2.959 .541 & 3.383 .228 \\
\hline Earning Per Share (dalam rupiah penuh) & $81.869,2$ & $141.455,6$ & $206.444,0$ & $276.579,4$ & $351.793,4$ & $423.686,8$ \\
\hline Price to Earning Ratio (Kali) & 16,59 & 15,02 & 11,29 & 9,43 & 8,41 & 7,99 \\
\hline
\end{tabular}

Price to Earning Ratio disingkat dengan PER merupakan rasio yang menggambarkan harga saham sebuah perusahaan dibandingkan dengan keuntungan atau laba yang dihasilkan perusahaan tersebut (EPS). Analisa PER suatu perusahaan dapat dilakukan dengan cara membandingkan PER dalam industri sejenis. Jika PER lebih kecil dari rata-rata emiten lainnya dalam industri sejenis, maka harga perusahaan dianggap relatif lebih murah. Membandingkan nilai PER dalam industri sejenis dapat menghasilkan kesimpulan apakah harga penawaran saham mahal atau tidak. Berikut ini adalah data EPS dan PER dari 15 emiten asuransi: 


\section{b. Analisa Kualitatif Strategi Perusahaan}

Data yang digunakan dalam analisa kualitatif strategi perusahaan diperoleh dari hasil focus group discussion. Nilai perusahan sebagaimana yang dijelaskan pada sub-bab sebelumnya menunjukan peningkatan kinerja yang progresif. Namun, diperlukan strategi perusahaan agar target-target kinerja sebagaimana diproyeksikan tersebut di atas dapat tercapai. Tentu dengan strategi yang tepat dapat mempertahan kan nilai perusahaan sesuai dengan proyeksi tersebut, bahkan dapat lebih baik. Berikut ini adalah pembahasan strategi perusahaan dalam rangka mempertahankan nilai perusahaan sesuai proyeksi kinerja tersebut:

\section{Input Stage- Analisa Five Porter's Model}

\section{a. The threat of a substitute product}

Terdapat dua perusahaan penjaminan yang full fledge yakni Askrindo Syariah dan Jamkrindo Syariah. Dengan demikian tingkat ketersediaannya subtitusi produk sangat sedikit. Adapun hal yang sangat mempengaruhi subtitusi produk ini adalah harga dan kualitas pelayanan.

\section{b. The threat of the entry of new competitors}

Ancaman terhadap munculnya kompetitor baru, pada industri penjaminan rendah. Hal tersebut disebabkan oleh ada nya barriers to entry yang cukup kuat. Sebagaimana diatur dalam Peraturan OJK No. 2 /POJK.05/2017 mengatur kegiatan usaha yang dilakukan penjaminan syariah bahwa perusahaan Penjaminan atau Perusahaan Penjaminan Syariah lingkup nasional wajib memiliki Ekuitas paling sedikit Rp100.000.000.000,00 (seratus miliar rupiah) dalam jangka waktu paling lama 3 (tiga) tahun setelah memperoleh izin usaha. Selain itu juga diatur batas gearing ratio yakni maksimal besarnya kafalah penjaminan secara keseluruhan yang dapat dijamin adalah $40 \mathrm{x}$ dari ekuitas perusahaan, dengan kafalah penjaminan produktif sebesar 20 x dari ekuitas perusahaan. Oleh karena itu untuk mengembangkan bisnis nya, perusahaan penjaminan sangat bergantung pada struktur permodalan.

\section{c. The bargaining power of customers}

Kekuatan penawaran dari pelanggan tinggi. Dimana pelanggan akan memperhitungkan efisiensi biaya untuk menggunakan jasa penjaminan apabila pelanggan masih mampu 
mengelola risiko kredit ataupun memilih kompetitor yang memberikan harga murah. Terutama untuk kredit yang memiliki agunan yang mudah untuk dieksekusi. Contoh pelanggan yang memiliki kekuatan penawaran sangat tinggi adalah Perum Pegadaian. Dimana hingga 5 tahun Askrindo Syariah melakukan inisiasi bisnis, belum terdapat kebutuhan untuk menggunakan jasa penjaminan. Faktor yang mempengaruhi kekuatan pembeli adalah produk yang sesuai dengan kebutuhan pelanggan dan kualitas pelayanan. Pelanggan mempertimbangkan antara harga dengan kualitas produk dan layanan seperti:

- Kebutuhan coverage nilai penjaminan yang tepat sesuai karakteristik produk, misalnya produk penjaminan kredit pensiunan dimana kecenderungan klaim terjadi akibat meninggal dunia. Maka pelanggan akan memilih produk dengan coverage meninggal dunia $100 \%$ dengan coverage wanprestasi akibat gagal bayar yang rendah saja. Hal tersebut lah yang akhirnya akan mempengaruhi harga.

- Kulitas layanan yakni kemudahan untuk mengakses produk yang dinilai dari metode dan SLA pengajuan pendaftaran penjaminan yang cepat dan mudah. Serta metode dan SLA pembayaran klaim.

\section{d. The bargaining power of supplier}

Kekuatan pemasok perusahaan penjaminan syariah rendah, disebabkan jumlah perusahaan pemasok (reasuransi) lebih banyak bila dibandingkan dengan pelaku industri penjaminan itu sendiri. Dengan banyaknya pemasok perusahaan reasuransi akan membuat industri penjaminan syariah dapat memilih pemasok bahan baku dengan harga murah dan kualitas yang baik.

\section{e. The intensity of competitive rivalry}

Askrindo Syariah memiliki sedikit pesaing namun masing-masing perusahaan bersaing secara kompetitif (ketat). Persaingan ini terjadi ditingkat harga, promosi / iklan, dan hadiah yang diberikan, hal ini ditunjukan untuk menarik minat para konsumen agar mau membeli produknya masing - masing.

\section{Input Stage- Analisa PESTLE}

Analisis PESTLE dikaji melalui beberapa faktor politik, ekonomi, sosial, teknologi, lingkungan, hukum dan lingkungan yang memengaruhi Indonesia saat ini. 
a. Faktor politik

Perkembangan politik yang sangat berpengaruh kepada keberlangsungan bisnis Askrindo Syariah yakni pembentukan Komite Nasional Keuangan Syariah (KNKS) sejak tahun 2017, oleh Presiden Joko Widodo. KNKS dibentuk pemerintah melalui Peraturan Presiden Nomor 91 Tahun 2016. Hal ini bertujuan guna mengembangkan potensi dan menjawab tantangan keuangan dan ekonomi syariah di Indonesia. Pembentukan Komite Nasional Keuangan Syariah adalah wujud komitmen pemerintah untuk mengembangkan ekonomi dan keuangan syariah di Indonesia secara serius dengan melibatkan seluruh pemangku kepentingan. Pada awal pembentukan Presiden Joko Widodo memimpin langsung KNKS ini dan Wakil Presiden Jusuf Kalla menjadi wakilnya. Dewan Pengarah diisi oleh Menko Perekonomian Darmin Nasution, Menteri PPN/Kepala Bappenas Bambang Brodjonegoro, Menteri Keuangan Sri Mulyani, Menteri Agama Lukman Hakim Saifuddin. Selain itu juga ada, Menteri BUMN Rini Soemarno, Menteri Koperasi dan UKM AA Gede Ngurah Puspayoga, Dewan Komisioner OJK Wimboh Santoso, Gubernur BI Agus Martowardojo, Ketua LPS Halim Alamsyah dan Ketua MUI KH Ma'ruf Amin. KNKS mendapat amanat untuk mempercepat, memperluas, dan memajukan pengembangan keuangan syariah dalam rangka mendukung pembangunan. KNKS berperan pula untuk menyamakan persepsi dan mewujudkan sinergi antara para regulator, pemerintah, dan industri keuangan syariah untuk menciptakan sistem keuangan syariah yang selaras dan progresif untuk pertumbuhan ekonomi Indonesia.

c. Faktor ekonomi

Pandemi Covid-19 yang terjadi di Indonesia memberi dampak signifikan terhadap pertumbuhan ekonomi, baik dalam skala nasional maupun daerah. Namun, Askrindo Syariah tetap memiliki peluang bisnis yang menjanjikan dalam mendukung upaya pemerintah dalam menjaga kestabilan pertumbuhan ekonomi nasional dilakukan dengan meluncurkan instrumen kebijakan berupa program Pemulihan Ekonomi Nasional (PEN). Dalam rangka program Pemulihan Ekonomi Nasional (PEN) 2020 pemerintah mengalokasikan dana sebesar Rp 19,7 triliun untuk lima Badan Usaha Milik Negara (BUMN) sebagaimana tertuang dalam Peraturan Menteri Keuangan (PMK) Nomor 118/PMK/06/2020 tentang Investasi Pemerintah dalam Rangka Program Pemulihan 
Ekonomi Nasional. Beleid ini berlaku mulai tanggal 2 September 2020. PMK 118/2020 ini merupakan aturan turunan dari Peraturan Pemerintah Nomor 43 Tahun 2020 tentang Perubahan astas Peraturan Pemerintah Nomor 23 Tahun 2020 tentang Pelaksanaan Program Pemulihan Ekonomi Nasional dalam rangka Mendukung Kebijakan Keuangan Negara untuk Penanganan Pandemi Corona Virus Disease 2019 (Covid-19) dan/atau Menghadapi Ancaman yang Membahayakan Perekonomian Nasional dan/atau Stabilitas Sistem Keuangan Serta Penyelamatan Ekonomi Nasional.

d. Faktor sosial

Ekonomi dan keuangan syariah mengalami perkembangan pesat dalam dua dasawarsa terakhir, baik secara global maupun nasional. The State of the Global Islamic Economy Report 2018/2019 melaporkan besaran pengeluaran makanan dan gaya hidup halal umat Islam di dunia mencapai USD 2.1 triliun pada tahun 2017 dan diperkirakan akan terus tumbuh mencapai USD 3 triliun pada 2023. Faktor utama yang mempengaruhi hal ini adalah peningkatan jumlah penduduk Muslim di dunia yang pada tahun 2017 mencapai 1.84 miliar orang. Jumlah ini akan terus meningkat dan mencapai 27.5 persen dari total populasi dunia pada 2030. Peningkatan populasi ini akan meningkatkan permintaan terhadap produk dan jasa halal secara signifikan.

e. Faktor Teknologi

Tidak bisa dipungkiri lagi saat ini teknologi sudah menjadi bagian dari kehidupan kita sehari hari. Perkembangan teknologi yang sangat pesat memengaruhi segala aspek termasuk dunia bisnis. Dalam bidang keuangan, juga tidak terlepas dari imbas kemajuan teknologi ini. Hal-hal yang biasa dilakukan secara manual sudah mulai diotomasi dengan teknologi. Salah satu bukti perkembangan teknologi dalam jasa keuangan ialah layanan perbankan digital seperti internet banking, mobile banking, dan lembaga finansial berbasis digital. Pemanfaatan teknologi dalam jasa keuangan, merupakan tantangan dan peluang bisnis bagi Askrindo Syariah. Demi mempercepat layanan penjaminan, Askrindo Syariah mengedepankan teknologi layanan digital. Di sisi lain, dalam rangka mengabsrop bisnis keuangan digital, salah satu sektor yang akan dimaksimalkan yakni penjaminan kepada perusahaan penyedia pinjaman berbasis online atau financial technology (Fintech). 
f. Faktor Legal

Ketentuan penyelenggaraan perusahaan penjaminan tercantum dalam POJK Nomor 2/POJK.05/2017 tentang Penyelenggaraan Usaha Lembaga Penjamin. Adapun faktor hukum yang merupakan sumber potensi bisnis penjaminan yakni ketentuan kegiatan lini usaha suretyship sebagaimana diatur dalam Pasal 4 ayat (2) UU Penjaminan menyatakan bahwa kegiatan ini dapat pula dilakukan asuransi berdasarkan Pasal 5 ayat (1) UU Perasuransian, yang telah mengatur adanya perluasan ruang lingkup kegiatan usaha perasuransian. Mengingat lini usaha suretyship yang diatur dalam Pasal 4 ayat (2) UU Penjaminan tidaklah memerlukan persyaratan sebagai lembaga penjaminan sebagaimana Pasal 1 angka 1 UU Penjaminan. Faktor Hukum berikutnya ialah ketentuan spin off unit usaha syariah perbankan syariah wajib dilakukan maksimal 15 tahun sejak diterbitkannya UU nomor 21 tahun 2008 tentang Perbankan Syariah atau paling lama pada 2023. Yang semakin meningkatkan potensi pasar.

f. Faktor Lingkungan

Faktor lingkungan yang dapat mempengaruhi kondisi kinerja Askrindo Syariah dapat berupa: Bencana alam, yang dapat memberikan risiko gagal bayar debitur atas kredit nya yang dijaminkan kepada Askrindo Syariah akibat kerusakan tempat usaha nya akibat bencana alam tersebut. Pandemi yang mengharuskan diberlakukannya pembatasan sosial berskala besar yang menimbulkan jatuh nya perekonomian terutama peningkatan risiko kredit macet.

\section{Input Stage- Matriks Eksternal Factor Evaluation (EFE)}

Berdasarkan hasil analisa PESTLE dan five porter's models sebagaimana dijelaskan sebelumnya, dirangkum pada matriks EFE sebagai berikut:

Tabel 17. Matriks Eksternal Factor Evaluation (EFE) 


\section{Peluang}

Program pemerintah penyaluran kredit PEN

(pemulihan ekonomi nasional)

Dukungan pemerintah dalam memajukan

perekonomian syariah

Penduduk Muslim mayoritas menjadi pangsa

pasar keuangan syariah

Spin Off dan Konversi seluruh Unit Usaha Syariah

Bank Pembangunan Daerah

TOTAL

Ancaman

TOTAL

\section{Bobot}

Rating

\section{Nilai}

0,4

$4 \quad 1,6$

0,2

$3 \quad 0,6$

0,1

$3 \quad 0,3$

0,3

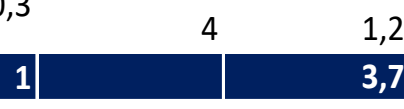

Bobot

Peringkat

Nilai

Pesaing berinovasi

0,5

1

0,5

Pandemi dan becana alam yang menyebabkan risiko kredit macet meningkat

TOTAL

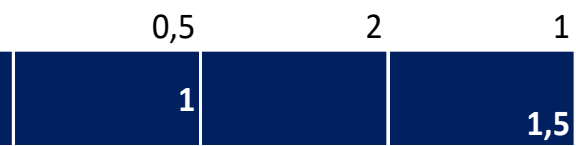

\section{Matriks Internal Factor Evaluation (IFE)}

Selain mengidentifikasi faktor-faktor ekternal, juga akan diidentifikasi faktor-faktor internal perusahaan sebagaimana berikut ini:

\section{Tabel. 18. Matriks Internal Factor Evaluation (IFE)}

\begin{tabular}{|c|c|c|c|}
\hline Kekuatan & Bobot & Rating & Nilai \\
\hline Sinergi antar entitas holding BUMN & 0,1 & 4 & 0,4 \\
\hline $\begin{array}{l}\text { Struktur permodalan yang kuat, tingkat gearing } \\
\text { ratio belum melampaui batas regulator }\end{array}$ & 0,1 & 4 & 0,4 \\
\hline $\begin{array}{l}\text { Portofolio investasi yang konservatif (deposito, } \\
\text { reksadana, obligasi) }\end{array}$ & 0,1 & 3 & 0,3 \\
\hline Layanan melalui digital platform & 0,1 & 3 & 0,3 \\
\hline Distribution channel tersebar seluruh indonesia & 0,05 & 3 & 0,15 \\
\hline $\begin{array}{l}\text { Hasil penilaian Good Corporate Governance } \\
\text { dengan hasil sangat baik }\end{array}$ & 0,05 & 3 & 0,15 \\
\hline $\begin{array}{r}\text { TOTAL } \\
\end{array}$ & 0,5 & & 1,6 \\
\hline
\end{tabular}


Segmentasi pelanggan berlum terkelola dengan baik

Portofolio bisnis sebagian besar pada produk dengan hasil underwritting kurang optimal

Pengelolaan beban usaha yang belum efisien

Piutang premi yang tinggi akibat kesepakatan penangguhan pembayaran dengan mitra bisnis

Minimnya sumberdaya manusia yang bersertifikasi

$0,05 \quad 2 \quad 0,1$

$0,1 \quad 3 \quad 0,3$

$\begin{array}{lll}0,05 & 2 & 0,1\end{array}$

$\begin{array}{lll}0,1 & 2 & 0,2\end{array}$

$\begin{array}{lll}0,05 & 2 & 0,1\end{array}$

TOTAL

7. Matching Stage - Analisa SWOT - Kekuatan (strength) dan Kelemahan (weakness), Peluang (opportunities) dan Ancaman (threats)

Analisa SWOT digunakan untuk meringkas dan mengevaluasi kekuatan dan kelemahan serta peluang dan ancaman utama dalam area fungsional bisnis Askrindo Syariah serta mengidentifikasi strategi nya.

Berdasarkan identifikasi kekuatan, kelemahan, peluang dan ancaman sebagaimana dijelaskan pada matrix IFE dan EFE maka berikut adalah table SWOT analisis:

Tabel. 19. Matriks SWOT 


\begin{tabular}{|c|c|c|}
\hline Eksternal & $\begin{array}{l}\text { Kekuatan } \\
\text { 1.Sinergi antar entitas holding BUMN } \\
\text { 2.Struktur permodalan yang kuat, tingkat } \\
\text { gearing ratio belum melampaui batas } \\
\text { regulator } \\
\text { 3.Portofolio investasi yang konservatif } \\
\text { (deposito, reksadana, obligasi) } \\
\text { 4.Layanan melalui digital platform } \\
\text { 5.Distribution channel tersebar seluruh } \\
\text { indonesia } \\
\text { 6. Hasil penilaian Good Corporate } \\
\text { Governance dengan hasil sangat baik }\end{array}$ & $\begin{array}{l}\text { Kelemahan } \\
\text { 1.Segmentasi pelanggan belum terkelola } \\
\text { dengan baik } \\
\text { 2. Portofolio bisnis sebagian besar pada } \\
\text { produk dengan hasil underwritting kurang } \\
\text { optimal } \\
\text { 3. Pengelolaan beban usaha yang belum } \\
\text { efisien } \\
\text { 4. Piutang premi yang tinggi akibat } \\
\text { kesepakatan penangguhan pembayaran } \\
\text { dengan mitra bisnis } \\
\text { 5. Minimnya sumberdaya manusia yang } \\
\text { bersertifikasi }\end{array}$ \\
\hline \begin{tabular}{l}
\multicolumn{1}{|c|}{ Peluang } \\
1. Program pemerintah penyaluran kredit \\
PEN (pemulihan ekonomi nasional) \\
2. Dukungan pemerintah dalam memajukan \\
perekonomian syariah \\
3. Penduduk Muslim mayoritas menjadi \\
pangsa pasar keuangan syariah \\
4. Spin Off dan Konversi seluruh Unit Usaha \\
Syariah Bank Pembangunan Daerah
\end{tabular} & $\begin{array}{l}\text { Memperluas pangsa pasar }(01,02,03,04, \\
\text { S1,S2,S4,S5) } \\
\text { Optimalisasi layanan digital platform } \\
(01,02,03,04, S 4)\end{array}$ & $\begin{array}{l}\text { Segmentasi pelanggan dan produk yang } \\
\text { profitable }(W 1, W 2, W 4,01,02,03,04) \\
\text { Peningkatan kompetensi pegawai } \\
(01,02,03,04, W 5)\end{array}$ \\
\hline $\begin{array}{l}\text { 1.Pesaing berinovasi } \\
\text { 2.Pandemi dan becana alam yang } \\
\text { menyebabkan risiko kredit macet meningkat } \\
\text { 3.Kesepakatan penangguhan pembayaran } \\
\text { dengan mitra bisnis, berpotensi } \\
\text { meningkatkan piutang premi }\end{array}$ & $\begin{array}{l}\text { Inovasi produk }(\mathrm{T} 1, \mathrm{~S} 1, \mathrm{~S} 2, \mathrm{~S} 4, \mathrm{~S} 5) \\
\text { Mengedepankan prudent underwritting } \\
(\mathrm{S} 2, \mathrm{~T} 2)\end{array}$ & $\begin{array}{l}\text { Evaluasi perjanjian kerjasama terkait tempo } \\
\text { pembayaran premi }(\mathrm{T} 3, \mathrm{~W} 3)\end{array}$ \\
\hline
\end{tabular}

\section{Decision Stage - Quantitative Strategic Planning Matriks (QSPM)}

Berdasarkan pada data faktor-faktor Setelah dilakukan tahap input analisis lingkungan internal dan eksternal melalui matriks IFE dan EFE. Serta tahap pencocokan dengan matriks SWOT, maka tahap selanjutnya yakni tahap keputusan dengan menggunakan QSPM. Teknik ini secara objektif mengindikasikan alternatif strategi mana yang terbaik. QSPM menggunakan input dari tahap pertama dan pencocokan dari tahap kedua untuk menentukan secara objektif diantara alternatif strategi. Penentuan skor daya tarik dilakukan dengan diskusi dengan peserta FGD, yaitu dengan mengamati setiap faktor tersebut apakah mempengaruhi terhadap pilihan strategi yang dibuat, dengan memberikan skor 1 (jika tidak memiliki daya tarik), 2 (jika daya tariknya rendah), 3 (jika daya tariknya sedang), dan 4 (jika daya tariknya tinggi). Alternatif strategi yang akan dipilih adalah sebagai berikut: 


\section{KESIMPULAN}

1. Berdasarkan analisis rasio-rasio keuangan perusahaan dalam kurun waktu 5 tahun terakhir, yakni analisa rasio-rasio likuiditas, solvabilitas, profitabilitas, dan rasio aktivitas dapat disimpulkan bahwa kinerja Askrindo Syariah baik dan bertumbuh. Meskipun pada tahun 2017 sempat terjadi penurunan dari sisi profotabilitas, namun pada tahun 2018 berhasil rebound dan lanjut meningkat pada tahun 2019. Pada tahun 2020 dimana terjadi pandemi Covid-19 yang menimbulkan keterpurukan ekonomi, kinerja Askrindo Syariah hanya menurun sekitar $15-25 \%$, namun tetap memberikan laba bagi pemagang saham.

2. Proyeksi kinerja perusahaan dalam kurun waktu 5 tahun mendatang telah disusun dengan memperhatikan trend kinerja sebelumnya serta asumsi-asumsi yang disesuaikan dengan kondisi bisnis di industri penjaminan. Dalam 5 tahun ke depan, kinerja Askrindp Syariah diproyeksikan meningkat dan progresif. Hal tersebut dudukung oleh strategi-strategi bisnis untuk mengakuisisi potensi pasar penjaminan syariah yang diproyeksikan akan semakin meningkat di 5 tahun mendatang.

3. Berdasarkan hasil analisa terhadap rentang nilai wajar harga saham terkait keputusan Askrindo Syariah melaksanakan IPO di tahun 2022, berdasarkan perhitungan free cash flow to equity nilai perusahaan di tahun 2022 adalah sebesar Rp 2.111.814.489.570,23,- dengan harga saham Rp 2.111.814,- per lembar saham, sedangkan berdasarkan valuasi relatif nilai book value adalah sebesar Rp Rp 2.331.168,- per lembar saham. Nilai price to earning ratio (PER) adalah sebesar 11,29 kali, sedangkan nilai earning per share (EPS) adalah sebesar Rp206.444.

4. Dalam penelitian ini juga dilakukan valuasi bisnis untuk mengetahui dan menganalisa perusahaan saat ini dan dalam kurun waktu 5 tahun mendatang. Berdasarkan hasil kinerja perusahaan tahun 2020, nilai perusahaan adalah sebesar Rp 568.238.558.651,65,- atau Rp568.239,- per lembar saham berdasarkan hasil perhitungan metode free cash flow to equity (FCFE). Sedangkan berdasarkan metode book value nilai perusahaan berada pada tingkat Rp1.358.268,50 per lembar saham. Dengan nilai PER 16,59 kali dan EPS Rp.81.869,-Berdasarkan perbandingan terhadap emiten asuransi lainnya, nilai PER masih berada dibawah rata-rata industri yang menunjukan angka sebesar PER 35,5 kali dan EPS berada di atas ratarata industri sebesar Rp147,20. Dalam kurun waktu 5 tahun mendatang, berdasarkan valuasi bisnis terhadap proyeksi kinerja perusahaan, pada tahun 2025 nilai perusahaan berdasarkan 
perhitungan menggunakan metode FCFE adalah sebesar Rp 2.929.706.160,073,33,- atau Rp2.929.706,- per lembar saham sedangkan berdasarkan metode book value adalah sebesar Rp3.383.228,- per lembar saham dengan nilai PER 7,99 kali dan EPS Rp.423.686,80. Adapun pertumbuhan rata-rata EPS adalah $27,5 \%$.

Untuk mempertahankan nilai perusahaan sebagaimana yang telah diproyeksikan, maka Askrindo Syariah perlu untuk menerapkan strategi perusahaan untuk mendukung pencapaian kinerja di 5 tahun mendatang tersebut, adapun strategi perusahaan dapat dilaksanakan sesuai dengan hasil analisa QSPM adalah peningkatan kualitas portofolio bisnis, yakni mengutamakan produk yang profitable.

\section{DAFTAR PUSTAKA}

Amri, A. (2021). Effect of Profitability, Asset Structure, Business Risk and Sales Growth on Capital Structure In Manufacturing Companies in Basic Industry Sector and Chemistry Listed in Indonesia Stock Exchange. Proceeding:The 1st International Conference on $\begin{array}{llll}\text { Regional Economic and } & \text { Development, }\end{array}$ https://doi.org/https://doi.org/10.32698/ICRED.0453

Amri, A., \& Ramdani, Z. (2020). Pengaruh nilai tukar, kebijakan deviden dan struktur modal terhadap return saham pada perusahaan yang terdaftar di jakarta islamic index. Jurnal Ilmu Keuangan Dan Perbankan (JIKA), 10(1), 17-36. https://doi.org/10.34010/JIKA.V10I1.3556

Ramadhi, Amri, A., \& Ramdani, Z. (2021). Studi terhadap faktor-faktor yang menentukan kinerja seorang karyawan. Jurnal Sains Manajemen, 7(2), 129-143.

Abdul, Rivai \& Darsono Prawironegoro. 2015. Manajemen Strategis (Kajian Manajemen Strategis Berdasar Perubahan Lingkungan Bisnis, Ekonomi, Sosial dan Politik, Jakarta: Penerbit Mitra Wacana Media.

Ali, S., \& Hartono, J. 2003. Pengaruh Pemilihan Metode Akuntansi terhadap Tingkat Underpricing Saham Perdana. Jurnal Riset Akuntansi Indonesia, Vol.6 No.1. Yogyakarta: Universitas Gajah Mada. 
Ari Wedhasmara. 2009. Langkah-Langkah Perencanaan Strategis Sistem Informasi Dengan Menggunakan Metode Ward and Peppard. Jurnal Sistem Informasi (JSI), VOL. 1, NO.

1. Palembang : Universitas Sriwijaya

Arifin, Ali. 2002. Membaca Saham. Yogyakarta : Andi

Arikunto, S. 2006. Metode Penelitian Kualitatif. Jakarta: Bumi Aksara.

Atmaji, Ayu Sukmaningrum Dwi. 2012. Analisis Fundamental Dalam Valuasi Saham Perdana PT Bank Pembangunan Daerah Jawa Timur Tbk. Jurnal Ilmiah Mahasiswa FEB Vol 1, No 2. Malang: Universitas Brawijaya

David, Fred R. (2011). Manajemen Strategis. Jakarta : Penerbit Salemba Empat.

David Fred R., Forest R. David (2015), Strategic Management : A Competitive Advantage Apporach, Concepts, and Cases, Edisi ke-15, New Jersey: Pearson Education.

Halim, Venny \& Yen Sun. 2013. Penilaian Bisnis Dan Estimasi Nilai Intrinsik Saham PT Waskita Karya (Persero) Tbk Saat Initial Public Offering (IPO). Tesis. Jakarta: Universitas Bina Nusantara.

Harahap. Sofyan, S. 2006. Analisis Kritis Laporan Keuangan. edisi 1-5. Jakarta: PT Raja. Grafindo Persada.

Kasiram, Moh. 2008. Metodologi Penelitian. Malang: UIN-Malang Pers.

Munawir, S. 2010. Analisis laporan Keuangan Edisi keempat. Cetakan Kelima. Belas. Yogyakarta: Liberty.

Paramadita, Siti et al. 2020. ANALISA PESTEL TERHADAP PENETRASI GOJEK DI INDONESIA PESTEL Analysis Towards GOJEK's Penetration in Indonesia. Jurnal Pengabdian dan Kewirausahaan Vol. 4 (No. 1) . Jakarta : Universitas Bunda Mulia.

Paskah, Robert Fajar. 2017. Estimasi Nilai Intrinsik PT. Asuransi Jasa Indonesia (Persero) Terkait Rencana Holding BUMN Asuransi Umum. Tesis. Jakarta: Universitas Gajah Mada.

Permata et al, 2013. Penilaian Saham Dengan Menggunakan Metode Price Earning Ratio dan Price Book (Studi Pada Saham PT Bank Rakyat Indonesia (Persero), Tbk Yang Terdaftar Pada Bursa Efek Indonesia Periode 2003-2012). Jurnal Administraasi Bisnis, Malang : Universitas Brawijaya. 
Rubiandini, maya. 2018, Formulasi Strategi Pemasaran produk Organik Pada PT Agatho Organis Agro. Tesis. Jakarta: Universitas Bina Nusantara.

Sheane,. 2019, Penilaian Nilai Wajar Saham Pt Ciputra Development Tbk August 2019Jurnal Manajemen Bisnis dan Kewirausahaan Vol 2(No.3), Jakarta: Universitas Tarumanegara.

Sugiyono. 2013. Metode Penelitian Pendidikan Pendekatan Kuantitatif,. Kualitatif, dan R\&D. Bandung: Alfabeta.

Syamsuddin, Lukman. 2007. Manajemen Keuangan Perusahaan. Jakarta: Raja Grafindo Persada

Tandelilin, Eduardus. 2010. Portofolio dan Investasi. Yogyakarta: Kanisius

Teddy, 2014. Analisis valuasi bisnis dan shareholder value pada PT Asuransi XYZ = Business analysis and valuation with shareholder value at PT Asuransi XYZ. Thesis Fakultas Ilmu Administrasi Universitas Indonesia.

Theresia Lesmana \& Yen Sun , 2013. Penilaian Bisnis dan Estimasi Nilai Intrinsik PT. Garuda Indonesia (Persero), Tbk saat Ipo Februari 2011. JURNAL BINUS BUSINESS REVIEW VOL. 4 NO. 1. Jakarta : Universitas Bina Nusantara.

Trienisa, Mira. 2021. Penilaian Harga Saham Wajar dengan Metode Discounted Cash Flow pada PT PP London Sumatra Indonesia TBK. Thesis. Pascasarjana ABFI Institute Perbanas : Jakarta.

Wahyuningsih, Sri. 2018. Analisis Fundamental Saham di Sektor Asuransi ( Studi Kasus Di Bursa Efek Indonesia 2014-2017) Jurnal Ilmiah Akuntansi dan Keuangan, Vol.7, No.02. Kebumen: Universitas Putra Bangsa. 